\title{
DUX4 wt Allele
}

National Cancer Institute

\section{Source}

National Cancer Institute. DUX4 wt Allele. NCI Thesaurus. Code C97464.

Human DUX4 wild-type allele is located in the vicinity of $4 \mathrm{q} 35.2$ and is approximately $2 \mathrm{~kb}$ in length. This allele, which encodes double homeobox protein 4, is involved in the modulation of transcription. This gene is within a D4Z4 repeat array; contraction of this macrosatellite repeat is associated with facioscapulohumeral muscular dystrophy (FSHD). A chromosomal translocation $\mathrm{t}(4 ; 19)(\mathrm{q} 35 ; \mathrm{q} 13)$ involving this gene and the $\mathrm{CIC}$ gene is associated with soft tissue sarcoma. 